\title{
The impact of securitisation and structural changes of Australian mortgage markets on bank pricing behaviour
}

\author{
Benjamin Liu* \\ Department of Accounting, Finance and Economics, Griffith Business School, \\ Griffith University, Queensland 4111, Australia \\ E-mail: b.liu@griffith.edu.au \\ *Corresponding author

\section{Michael Skully} \\ Department of Accounting and Finance, Faculty of Business and Economics, \\ Monash University, Victoria 3145, Australia \\ E-mail: michael.skully@buseco.monash.edu.au
}

\begin{abstract}
This paper investigates the impact of securitisation and structural changes of the Australian mortgage market on bank pricing behaviour. Since the mid 1990s, securitisation has dramatically increased and thus intensified competition between banks and mortgage corporations (new entrants). To respond to the competition, banks largely reduced their mortgage interest rates. However, there is no study on what caused their price reductions. We present a simple model to explain potential factors that may affect bank behaviour. It is the first time to examine this issue from both perspectives of cost effects and market structural changes by testing four major bank data. It finds that lender yield spreads are significantly related to bank market share, existing and new loan concentration indexes, and securitisation respectively. Findings further indicate that declined concentration and increased competition have significantly caused lender spread changes. The findings are consistent with both securitisation literature (e.g., Gorton and Pennacchi, 1995; Kolari et al., 1998; Ambrose et al, 2004).) and price-concentration studies (e.g., Berger and Hannan, 1989).
\end{abstract}

Keywords: securitisation; competition and market structure; bank pricing behaviour.

Biographical notes: Benjamin Liu received his $\mathrm{PhD}$ in Finance at Monash University and now is Lecturer of Finance at Department of Accounting, Finance \& Economics, Griffith Business School of Griffith University (Australia). He also is a CMA of the Institute Certified Management Accountants, the member of American Finance Association and Accounting \& Finance Association of Australia and New Zealand. His research interests include issues in relation to securitisation, structured products and mortgage finance, risk management for financial institutions, asset pricing, financial market integration, corporate finance, equity valuation and financial modelling.

Michael Skully is Professor and the Chair of Banking at Monash University (Australia). He is a senior fellow of Financial Services Institute of Australasia, a fellow of CPA Australia, and a director and vice president of the Asia Pacific Finance Association. He has published widely in the areas of financial institutions and corporate finance both in respect to Australia and the Asia Pacific region. Some of his books include Merchant Banking in Australia, co-author of Management of Financial Institutions; and the general editor of the Handbook of Australian Corporate Finance. 


\section{Introduction}

Securitisation, also known as structured finance, represents one of the most fascinating financial innovations and capital market developments over the last three decades. Particularly, in the wake of the recent sub-prime crisis, securitisation has attracted a widespread attention by the public, academic, regulators and any other concerned parties. Like any other financial innovations, it brings some unique benefits and potential problems as well. This paper, from an alternative perspective, is to examine the impact on bank pricing behaviour in Australia.

Mortgage securitisation, more recently in Australia, plays an increasing role in mortgage finance, having a dramatic growth after 1997 particularly. Total securitisation outstanding surged from AU\$ 2.05 billion in December 1988 to AU\$ 142.26 billion in December $2003^{1}$. Mortgage securitisation is the largest contributor for the increase, from AU\$ 1.303 billion to AU\$ 105.97 billon. This market ranked second to USA in size. Australian mortgage markets differ from USA in several ways. Since the earlier 1990s, mortgage corporations ${ }^{2}$ have been active, becoming major players in the securitisation market eventually. The Australian primary market is also quite unique. Four major commercial banks ${ }^{3}$ have traditionally dominated the market, with around $60 \%$ of market share of own-occupied home loans in 1994, and had some declines in recent years. More interestingly, nearly 80 percent of Australian mortgages are originated with adjustable rates. Any reductions in interest rate, therefore, have a greater impact on borrowers' costs because not only existing loans but also newlyoriginated ones are more sensitive to any rate adjustments.

Since the early 1990s, securitisation has enabled mortgage corporations to establish in Australia and to securitise their loans (nearly 100\%) in both the domestic and global capital markets for raising cheaper funds and then lending them to borrowers. The whole recycling process allows them to grow quickly and compete with the traditional lenders, such as commercial banks, by providing cheaper and new products (currently about 2,000 products in the market). As a result, for instance, the bank market share of newly-originated loans declined from 90 percent in 1994 to 77 percent in 2003. To respond to increasing competition, bank yield spreads (over 90-day bank bill rates) of nearly 4 percent in 1994 dropped to 1.5 percent by 2003. A key research problem examined in this paper is what factors may affect bank pricing behaviour. 
We borrow ideas from economic literature on the relationship of price setting behaviour, and competition and concentration. For example, the price-concentration research ${ }^{4}$ considers market concentration as exogenous factors to bank pricing behaviour and suggests that high concentration allows for non-competitive behaviour that leads to less favourable prices to consumers (e.g., Berger and Hannan, 1989). Cetorelli and Strahan (2006) strongly support the idea that potential entrants encounter a greater difficulty to access to credit in a concentrated banking market than in a competitive market. With this sense in mind, without securitisation funding, mortgage corporations could not exist, and thus the banking market would remain at a high degree of concentration as before.

Because little empirical research on this issue can be found, particularly in an Australian context, this paper attempts to fill the gap and thus makes several contributions to literature. This motivates us to further investigate the issue. It should be the first to examine the impact of securitisation on bank pricing behaviour in both cost reduction and competition perspectives as previous literature has not directly addressed the market structural change due to securitisation. It also is the first work to examine the dynamic relation between lender spread changes and concentration, competition and securitisation.

To address the above mentioned research problem, firstly, we use a simple model to illustrate how the possible factors may affect bank pricing behaviour. After that, regression and Granger Causality tests are used to examine monthly data of standard adjustable rate mortgages (SARMs) of the four major banks between 1994 and 2003. We collectively follow methodologies that are used in securitisation research (e.g. Black et al 1981; Kolari et al, 1998; Naranjo and Toevs, 2002; Ambrose et al, 2004) and price-concentration studies (e.g. Berger and Hannan, 1989; Corvoisier and Gropp, 2002).

The rest of this paper is organised as follows. Section 2 reviews the relevant literature on cost effects associated with securitisation, and banking concentration and pricing behaviour. Section 3 discusses the basic model pertaining to the research problem, describes data and defines variables that are used for model tests. Section 4 reports empirical results and discusses the findings. Conclusions are drawn in Section 5.

\section{Literature review}


Two broad aspects of securitisation ${ }^{5}$, both theoretical and empirical, are reviewed, which are considered to be most relevant to our research problem. The existing empirical work with respect to securitisations' effects on mortgage costs also is summarised. In addition, price-concentration literature with regard to bank pricing settings is briefly covered.

\subsection{Potential benefits of securitisation}

Liquidity research predicts a direct effect of securitisation on bank liquidity risk and marketability, as well as the market as a whole. Berger and Udell (1993) state that banks with high loan sales volume have superior ability to securitise their remaining assets compared to low sales banks. Therefore, securitisation activity is negatively associated with liquidity risk. Gorton and Pennacchi (1995) suggest that the banking industry as a whole is more liquid with the growth of loan sales.

There are at least four dimensions relating to liquidity:

1. Overall mortgage marketability and liquidity are improved through securitisation (e.g., Black et al., 1981; Gorton and, Pennacchi, 1995; Kothari, 2006);

2. The process of securitisation change the nature of assets (e.g., Schwarcz, 1994; Hill, 1997), transforming illiquid assets (e.g., mortgages) into marketable securities;

3. Security designs with pooling and tranching enhance asset liquidity (e.g., DeMarzo, 2005), reallocating cash flows, risks and information;

4. Banks' liquidity positions are strengthened (e.g. Berger and Udell, 1993; Thomas and Wang, 2003).

Funding cost studies (e.g., Hill, 1997; Schwarcz, 1994; Iacobucci and Winter, 2005) suggest that securitisation's purpose is to low funding costs for the firm by separating the originator's receivables via securitisation from its associated risks. It effectively alters the approach of the credit rating from a company based to an asset based as the asset's ownership is legally separated from its originators. Thus the originator can then use these assets to raise funds in the capital markets at a lower cost than by directly issuing more of its own debts or equity.

Researchers (e.g., Greenbaum and Thakor, 1987; Cumming, 1987; Pennacchi, 1988; Wolfe, 2000) support the view that securitisation banks can reduce their reserve, capital requirements and deposit insurance premium ${ }^{6}$, known as "regulatory tax". 
Some other authors (e.g., Hess and Smith 1988) indicate that securitisation can be used as an asset and liability tool to manage credit risk, interest rate risk, liquidity risk, prepayment risk and portfolios for financial institutions.

Furthermore, Hill (1997) and Gorton and Souleles (2005) predict that Special Purpose Vehicles (SPVs) in securitisation helps reduce bankruptcy costs. Hill (1997) and Iacobucci and Winter (2005) suggest that securitisation process can help reduce information cost and an asymmetric information problem between the investors (as lenders) and the company (as borrowers). Securitisation can solve the 'lemon problem' when the company faces financing difficulties and then reduce information costs about company's receivables. In addition, some studies (e.g. Iacobucci and Winter, 2005) suggest that securitisation can lower agency costs and underinvestment problems.

\subsection{Empirical evidence}

The above mentioned cost effects in theory (to the originator and the market as a whole) are reflected in mortgage costs. Empirical work of securitisation on yield spreads or rates follows two broad approaches. The first approach (e.g., Black et al., 1980; Kolari et al., 1998) uses series data to test effects of securitisation over time. Their results generally support the view that the growth of MBS markets in terms of improved marketability and liquidity significantly affects mortgage costs. For, example, Kolari et al. (1998) and Naranjo and Toevs (2002) who use multivariate cointegration to test the U.S. fixed rate mortgage (FRM) yield spreads find a long term relation of securitisation to yield spreads, but do not find the relation of default risk to the spreads. Kolari et al. find that 10 percent of increase in securitisation leads to a decrease of 20 basis points in the yield spreads.

Besides testing the influence of GSEs' activities on mortgage market yields, Naranjo and Toevs (2002) further examine:

1. the yield differences between conforming and non-conforming loans;

2. the spillover effects of GSEs' purchase on non-conforming loans because both types

of mortgage loans are originated in a single market, in terms of investor substitutions; 3. volatility of mortgage interest rates.

They find that increased GESs' activities and securitisation reduce the yield spreads of both conforming-and non- conforming loans, narrow the differences between the two types of loans (lender yield spreads), as well as stabilise interest rates over time. 
The second approach uses lenders or loans level data to investigate securitisation's effects on originator pricing behaviour (e.g., Hendershott and Shilling, 1989; Benjamin et al., 1994; Ambrose et al, 2004; Liu and Skully, 2005). Using different U.S. datasets they consistently find that mortgage banks that securitise their assets have lower mortgage rates or spreads than depository institutions. Liu and Skully, using Australian cross-sectional data, generate the similar findings.

\subsection{Market structure and bank pricing behaviour}

\subsubsection{Structural change in the mortgage market}

More interestingly, securitisation promotes not only specialisation, but also competition in mortgage lending, such as the growth of mortgage banks in the USA and mortgage corporations in Australia. One of the most interesting trends is that increasing market share is held by mortgage banks as non-depository institutions.

As mortgage corporations grows quickly in Australia, O’Connell $(1997$, p.8) states:

"banks have already met this challenge of real competition in the housing mortgage market ... mortgage originators have opened up competition and have challenged the banking industry to cut margins and profits in home lending, ultimately for the benefits of consumers."

Kumar and Ralston (1999) concludes that the increase in mortgage managers' market share from 1992 to 1996 can be attributed to factors underlying the competitive advantages of competitive pricing and securitised funding. Without securitisation they would be very difficult for mortgage corporations to have entered the Australian market, as constrained by deposits and the regulatory regime. They suggest that securitisation has caused the market structural change in terms of declined concentration held by traditional banks.

\subsubsection{Market concentration and bank pricing behaviour}

There are two main explanations for the changes of mortgage yield spreads of individual banks or the industry as a whole: 
1 markup theory (e.g. Rousseas, 1985)

2 the price-concentration relationship (e.g. Berger and Hannan, 1989).

Both are related to competition and pricing in a specific banking area (i.e. the degree of oligopoly or any other barriers to entry), such as mortgages, credit cards or business lending.

Rousseas $^{7}$ (1985) uses the markup theory to model the pricing of bank loans $i=$ $k(u)$, where $i$ is the interest rate on loan, $k$ the degree of monopoly or market power exercised by individual banks, or in the aggregate, by the banking industry as a whole and the $u$ the unit prime or variable costs incurred by banks.

Some studies apply structure-performance theory to the banking price-setting (priceconcentration relationship) (e.g. Gilbert, $1984^{8}$; Berger and Hannan, 1989 Corvoisier and Gropp, 2002). This approach assumes market structure, as an exogenous factor, impacts on bank pricing behaviour. They found a positive relationship between bank concentration (less competitive behaviour) and credit price. In more concentrated market banks will price their loans and deposits less favourable to consumers.

In summary, the above-mentioned research motivates us to reconsider the possible impacts of securitisation on bank pricing behaviour in two ways. Securitisation might have reduced originators' mortgage costs through improved mortgage marketability and liquidity. This is reflected in narrowed yield spreads or margin costs. At the same time, securitisation might have caused the structural change of the mortgage market, and the shift, in turn, might have affected bank pricing behaviour. This is demonstrated in the yield spreads too. However, no empirical study addresses the second issue.

\section{Methodology and data}

\subsection{Simple model for lender yield spreads}

For simplicity, this section presents the simple model to explain lender yield spread and its relationships with explanatory variables. According to the theoretical and empirical work on securitisation's cost effects detailed in the previous literature, Australian lenders can broadly be modelled into three groups: total deposit originators $(T S O s)$, partial securitisation originators $(P S O s)$ and total securitisation originators $(T S O s)^{9}$. According to the securitisation literature, TDOs have the highest average unit 
cost while TSOs have the lowest one. PSOs are placed in the middle. $C^{d}$ is assumed to be the average unit cost for TDOs, $C^{d s}$ for PSOs and $C^{s}$ for TSOs, respectively, and thus $C^{d}>C^{d s}>C^{s}$ or $\left(C^{d}-C^{s}\right)>0$ and $\left(C^{d s}-C^{s}\right)>0$.

Rousseas (1985) assumes that the endogenous factor, lenders' funding costs, determine their price. Lending interest rates are based on their costs of funds. Interest rate spreads are needed to achieve their profit goal. The interest rate spread (also known as the margin or markup) is the difference between a banks' funding costs and what a bank charges on loans. In Rousseas's study the lender requires just a normal return $\left(R^{n}\right)^{10}$, which is also assumed constant over time. Thus, the excess return $\left(R^{e x}\right)$ would be zero in a competitive market. The studies (e.g., Sirmans and Benjamin, 1990) predict that, in a competitive market, the excess return on assets should be nearly zero $\left(R^{e x} \approx 0\right)$. In such markets, mortgage pricing is only based on the originators' unit costs, $C^{11}$.

Further we assume $r^{d}$ as interest rates for TDOs, $r^{d s}$ for PSOs and $r^{s}$ for TSOs. Because of their unit cost differences, $\left(r^{d}-r^{s}\right)>0$ and $\left(r^{d s}-r^{s}\right)>0$. Mortgage corporations should have the lowest rate, $r_{s}$. However, these comparisons are limited to cost effects of securitisation only. In a less competitive market, like the Australian banking sector, however, the return on assets is assumed to consist of two components: a normal return $\left(R^{n}\right)$ and an excess return $\left(R^{e x}\right)$.

In addition to the markup theory, the price-concentration literature (e.g., Berger and Hannan, 1989; Corvoisier and Gropp, 2002) suggests the excess return $\left(R^{e x}\right)$ is not zero in a less competitive and more concentrated market. Market concentration and competition are regarded as exogenous factors to lender pricing-settings. For example, banks will tend to price their loans and deposits less favourably to consumers when operating in a concentrated market (e.g., Berger and Hannan, 1989).

Securitisation may impact on Australian mortgage pricing settings over the period 1994 to $2003^{12}$ in two ways. Over this period, securitisation may has not only improved mortgage marketability and increased integration of the mortgage market and capital market ${ }^{13}$, but also led to the market structural change. This change, in turn, may have affected bank pricing behaviour.

Since the early 1990s, mortgage corporations have become important and securitised all their loans (nearly a 100\%). They have gained market share and increasingly competed with traditional lenders, such as commercial banks, by providing cheaper and new products. As a result, for instance, the bank share of newly 
originated loans dropped from 90 percent in 1994 to 77 percent in 2003 . For the same period, bank yield spreads of nearly 4 percent in 1994 had declined to around 1.5 percent by 2003. The increased competition that caused this result did not come from within the depository institutions, but rather from newly entered and differently natured mortgage corporations.

The following equations ( 1 to 5) help to explain the impact of securitisation and the market structural change on lender yield spreads. Equation 1 is derived for the interest rate when considering both components (costs and returns):

$r_{i}=C_{i}+R_{i}^{n}+R_{i}^{e x}$

Where $r=$ interest rate, $C=$ average unit cost, ${ }_{i}$ for TDOs, PSOs and TSOs, $R$ for return rate, ${ }^{n}$ for normal and ${ }^{e x}$ for excess.

Thus for banks as a whole, ${ }_{b}$, either TDO or PSO

$r_{b}=C_{b}+R_{b}^{n}+R_{b}^{e x}$

For mortgage corporations as a whole, ${ }^{m}$ for $T S O$

$r_{m}=C_{m}+R_{m}{ }^{n}+R_{m}{ }^{e x}$

When further assuming that the normal return for banks and mortgage corporations is the same: $R_{b}{ }^{n}=R_{m}{ }^{n}$. When Eqs.(2) subtracts Eqs. (3), we derive lender spreads as follow:

$\left(r_{b}-r_{m}\right)=\left(C_{b}-C_{m}\right)+\left(R_{b}^{e x}-R_{m}^{e x}\right)$

Where $L S P=\left(r_{b}-r_{m}\right)$ is the lender spreads between banks and mortgage corporations. Because mortgage corporations, fully funded through securitisation, are new entrants in the market, they need to survive and compete with traditional lenders so their excess return is reasonably assumed to be close to zero, $R_{m}{ }^{e x} \approx 0$. Similarly, Kumar and Ralston (1999) do not find a positive relationship between mortgage corporations' yield spreads and their market share.

Therefore, Eqs.(4) can be rewritten as:

$L S P=\left(r_{b}-r_{m}\right)=\left(C_{b}-C_{m}\right)+R_{b}^{e x}$

Thus $d L S P / d R_{b}^{e x}>0$ or there is a positive relationship between $L S P$ and $R_{b}^{e x}$ as long as $\left(C_{b}-C_{m}\right)>0$.

$R_{b}{ }^{e x}$ in Eqs.(5), the bank excess return, is very sensitive to the market structural factor (concentration and competition), and thus $L S P$ behaves similarly. If $\lambda$ is assumed to be a concentration indicator (HHI index ${ }^{14}$ ) and $\mu$, to be a competition indicator (bank market share), both $R_{b}^{e x}$ and $L S P$ should positively be associated with $\lambda$ and $\mu$ 
respectively. O'Connell (1997) points out that securitisation enables mortgage corporations to compete with banks, in turn, to respond to the change, banks cut their margins. Therefore, it is expected to have a positive relationship for the research period between the lender yield spreads (LSP), and the two concentration indexes (HHIa and HHIb) and three market share variables (BMS, BIMSa and BIMSb) (see details in Table 1).

In addition, based on securitisation-liquidity literature (e.g., Black et al 1981; Gorton and Haubrich, 1995; Kolari et al, 1998), the growth of the securitisation market helps improve overall mortgage marketability. The average unit cost for banks, $C_{b}$, declines, associated with the growth of the securitisation market and major banks' direct securitisation involvements as banks moved from TDOs to PSOs since 1997. Alternatively, commercial banks may view the increased securitisation market as disintermediation signalling more competition to come so that securitisation may have spillover effects on bank pricing behaviour, also demonstrated in LSP. Naranjo and Toevs (2002) find the spillover effect on jumbo loans in U.S. According to these two explanations, $L S P$ is expected to have a negative relation to the growth of securitisation.

Furthermore, this paper that examines lender yield spreads (LSP), rather than yield spreads over a market index, could more accurately reflect the impact of securitisation and the market structure on bank pricing behaviour. Because banks and mortgage corporations operate in the same market, $C_{b}$ and $C_{m}$ consist of the same level of market prepayment risk, market default risk premium and other risks (see Black, et al, 1981; Kolari et al., (1998) and market interest rates (e.g., 90-day bank bill rates) at a time. $\left(C_{b}-C_{m}\right)=\Delta C$ will cancel out all these common cost factors and the remainder that is the lender idiosyncratic risk and cost is more relevant to securitisation and market structural factors. Therefore, lender spreads, $L S P$, may more sensitively relate to market concentration and competition, as well as securitisation. This will specifically examine the impact of securitisation and market structural change on lender pricing behaviour and then address the research problem.

\subsection{Data description and variables definitions}

Data are collected from monthly statistics of Reserve Bank of Australia (RBA), covering the period of from January 1994 and December 2003. They include the 
average standard adjustable interest rates for the banks (the major bank average) and mortgage corporations ${ }^{15}$, aggregate mortgages outstanding, mortgages outstanding (excluding securitised loans) for all banks, building societies and credit unions, and aggregate mortgage securitisation.

The four major banks' home loan data (owner-occupied housing lending) for the research period are collected from the monthly statistics of Australian Prudential Regulatory Authority (APRA). In order to remove the impact of mergers and acquisitions (between 1994 and 2003) on market share of these four banks and thus reflect their real market positions, their home loan data deduct acquired banks' ones from their consolidated balance sheets. Their market shares are the percentage of overall owner-occupied mortgage outstanding. In addition, the four major banks' interest rate data is collected from the monthly survey of CANNEX Australia from 1994 to 2002. Data of newly contracted loans are collected from monthly survey of Australian Bureau of Statistics (ABS).

In order to calculate bank market share and concentration index (HHI) more accurately individual mortgage collateral data for each securitised pool from 1995 for banks, building societies, credit union and mortgage corporations are collected from multiple sources. They are collected from Standard and Poors' ABS performance statistical data, Perpetual Trustees Australia, National Australia Bank, Moodys', FITCH, and individual MBS issuers. The data added back to each respective group to derive the market share of each industry and calculate the Herfindahl-Hirschman Index (HHI).

Variables that are used for testing models in the next section are summarised in Table 1. Lender spreads (LSP) are monthly standard adjustable interest rates differences between banks and mortgage corporations for the research period. In the OLS regression models, lender spreads (LSP) is the interest rates difference between each of the four major banks' rates and average mortgage corporations' rates (as a benchmark rate) at time $t$. In the Causality model, it is the interest rates difference between their average rates at time $t$. Market concentration is proxied by two Herfindahl-Hirschman Indexes (HHIa and HHIb) that are sum of squared outstanding market share of bank, building society, credit union and mortgage corporation groups, and sum of squared new loan market share of these four groups respectively. Competition is proxied by three measures separately. They at time $t$ are each market share of the four major banks (BMS), bank industry aggregated market share (BIMSa), 
and bank industry aggregated new loan market share (BIMSb). BMS is market share of each of the four major banks in overall owner-occupied mortgage outstanding. BIMSa and BIMSb are bank industry market share (aggregate) in overall owner-occupied mortgage outstanding and newly originated mortgages (aggregate) respectively. Securitisation proxies for marketability and liquidity by the annual growth rate of overall mortgage securitisation outstanding. To capture trends, the year dummy from 1994 to 2003 is also included. In the regression, the year of 1994 is controlled as the reference (basis year $=0$ ) and all other years are tested (their values $=1$ ).

[Insert Table 1 about here]

\subsection{Regression on lender yield spreads}

The following generic regression (pooled) includes four models to test the relationship between LSP and individual bank market share, securitisation, overall concentration, new loan concentration and trends (year for the trend effect). The first model (Model 1) only tests for the relationship between lender spreads (LSP) for the four major banks, and their market shares (BMS) and securitisation (SECTZ). In the second model (Model 2), market concentration index (HHIa) replaces market shares of the major banks in Model 1. The third model (Model 3) replaces existing loans market concentration in Model 1 with the newly-originated loan concentration index ( $\mathrm{HHIb}$ ). The fourth model (Model 4) also considers the trend (the year effect to capture trends). These three variables (BMS, HHIa and HHIb) have high levels of correlations between a pair so we separately test each one

$$
L S P_{i}=\beta_{0}+\beta_{1}\left[\text { BMS }_{i} \text { or HHIa } \text { or HHIb }_{i}\right]+\beta_{4} \operatorname{SECTIZ~}_{i}+\Sigma \beta_{k} \text { Year }_{k}+\varepsilon_{i}
$$

Where LSP is the lender spreads of four major banks over mortgage corporations for the period from 1994 to 2002; BMS, monthly market share of each of four major bank; SECTIZ, marketability and liquidity change via the annual growth rate of overall mortgage securitisation; HHIa for the Herfindahl-Hirschman Index of residential loan outstanding as a measure of concentration; HHIb for the Herfindahl-Hirschman Index of the newly originated residential loan as a another measure of concentration; Year for trend, from 1994 to 2002. 


\subsection{Granger Causality test}

This paper also uses the Granger Causality test ${ }^{16}$ to examine the dynamic relationship of a pair of series, lender spreads (LSP) with securitisation (SECTZ), concentration (HHIa and HHIb) and competition (BIMSa and BIMSb) respectively. If series data are stationary, or $I(0)$ from both the ADF and PP unit root tests, the Granger Causality test is:

$$
\begin{gathered}
\mathrm{Y}_{t}=\alpha_{y}+\sum_{i=1}^{k} \beta y, i \quad \mathrm{Y}_{t-i}+\sum_{i=1}^{k} \lambda \mathrm{y}, i \quad \mathrm{X}_{t-i}+\varepsilon_{y, t} \\
\mathrm{X}_{t}=\alpha_{x}+\sum_{i=1}^{k} \beta x, i \\
\mathrm{X}_{t-i}+\sum_{i=1}^{k} \lambda \mathrm{x}, i \\
\mathrm{Y}_{t-i}+\varepsilon_{x, t}
\end{gathered}
$$

Where $Y_{t}$ is the spreads of banks over mortgage corporations (lender spreads, LSP) at the time $\mathrm{t} ; \mathrm{X}_{\mathrm{t}}$ is the securitisation (SECTZ), concentration indexes (HHIa and HHIb) and bank industry market share (BIMSa and BIMSb) respectively; $\alpha_{y}$ and $\alpha_{x}$ are the intercepts; $\varepsilon_{\mathrm{y}, \mathrm{t}}$ and $\varepsilon_{\mathrm{x}, \mathrm{t}}$ are the white noise error terms; $\beta$ and $\lambda$ are the parameters of the lagged value $\mathrm{Y}$ and $\mathrm{X}$ respectively.

If a level series is non-stationary, $I(1)$ based on ADF and PP tests, as Gujarati (2003) suggests, a series will be converted into an $I(0)$ by using its first difference: $\Delta \mathrm{Y}_{\mathrm{t}}$ is the first difference of lender spreads at the time $t ; \Delta X_{t}$ is the first difference of the securitisation, concentration index and market share at the time $t$ respectively.

The test of causality is based on the $F$-statistic through estimating expressions in both restricted and unrestricted forms (see Gujarati, 2003). It can be expressed as the following;

$$
F=\frac{\left(S S E-S S E_{U R}\right) / m}{S S E_{U R} /(T-2 m-1)}
$$

Where $S S E$ and $S S E_{U R}$ are the residual sum of squares of the restricted and unrestricted models respectively; $T$ denotes the number of observations; $m$ stands for the number of lags. The $F$-statistic follows a $\chi^{2} / m$ distribution.

\section{Empirical results and discussions}




\subsection{Regression results for lender spreads}

This section reports on regression results of lender yield spreads using the four models separately, as shown Tables 2 and 3. In Panel A of Table 2, lender spreads for the four major banks are positively associated with their market shares (BMS) at the 1 percent level of significance, but negatively with the growth of securitisation at the same level.

[Insert Table 2 about here]

As shown in Panel B, lender spreads are significantly and positively associated with the existing loan concentration index, HHIa (at the 1 percent level) while they are significantly and negatively with securitisation, SECTZ (at the 1 percent level). Similarly, when replacing this concentration index with the new loan concentration index, as shown in Panel $\mathrm{C}$, their spreads still have a significant relation to securitisation at the 5 percent level, and to new loan concentration index, HHIb (at the 1 percent level).

[Insert Table 3 about here]

We further examine whether trends (via year) have any impacts on their spreads. As shown in Table 3, there still are the same significant relationships between their spreads and the concentration index (HHIa, at the 1 percent level) and securitisation (SECTZ), at the 1 percent level). When taking the year, 1994 as the reference, all years from 1997 to 2002 except for 2001 are negatively and significantly related to the spreads. Since 1997, securitisation has substantially grown and allowed more mortgage corporations to be established and further intensify competition for originating mortgages. At the same time, the major banks, such as Westpac and Commonwealth banks, started to securitise their home loans through their own securitisation programs.

Therefore, the above findings are consistent with securitisation literature (e.g., Black et al, 1981; Kolari et al, 1998) and price-concentration studies (e.g., Berger and Hannan, 1989). Without the growth of mortgage securitisation, it would be impossible that to some extent, the dominated position of the four major banks was challenged and weakened in the primary mortgage market. 


\subsection{Granger Causality test for lender yield spreads}

This section reports results on the dynamic relationship between lender yield spreads and market concentration, competition and securitisation. The Granger Causality test is used to examine whether the first difference of competition, concentration and marketability has respectively caused the first difference of lender yield spreads ( $\Delta$ LSP) for the research period ${ }^{17}$ and vice versa.

Causality relationships in F-statistics are presented in Table 4. As shown in Panel A of Table 4 , the first four variables in their first difference ( $\triangle \mathrm{BIMSa}, \triangle \mathrm{BIMSb}, \Delta H H I \mathrm{a}$ and $\Delta \mathrm{HHIb}$ ) independently cause the change of lender spreads ( $\triangle \mathrm{LSP}$ ) in the first two lags, with the F-statistic at equal to or below the 0.05 level of significance. The new loan concentration index $(\Delta \mathrm{HHIb})$ is still significant to $\Delta$ LSP across all the six lags. These results suggest that declined market concentration and increased competition caused lender spreads narrowed.

\section{[Insert Table 4 about here]}

However, as shown in Panel B of Table 4, the first difference of lender spreads ( $\triangle \mathrm{LSP}$ ) do not cause all the first four variables ( $\triangle \mathrm{BIMSa}, \triangle \mathrm{BIMSb}, \Delta \mathrm{HHIa}$ and $\Delta \mathrm{HHIb}$ ) in all the six lags respectively, except for the new loan concentration $(\Delta \mathrm{HHIb})$ and securitisation $(\triangle \mathrm{SECTZ})$ in the first lag (at 0.05 level). The finding indicates that there is no feedback relation.

The above findings further suggest the increased competition and declined concentration in the mortgage market have impacted on changes of lender yield spreads. This further is consistent with the price-concentration literature (e.g., Berger and Hannan, 1989; Corvoisier and Gropp, 2002), and Australian research (e.g., Kumar and Ralston, 1999; O’Connell, 1997).

Similarly, marketability ( $\triangle \mathrm{SECTZ})$ in Panel A also significantly causes the spread in the first two lags (at the 0.5 level). This suggests that improved mortgage marketability and liquidity may also affect the spreads. This is also consistent with securitisationrelated literature (e.g., Black et al, 1981; Kolari et al, 1998; Ambrose et al, 2004). In addition, securitisation may have a spillover effect on lender spreads because all lenders operate in the same market, evidenced in Narano and Toevs (2002). Thus, securitisation may also impact on bank pricing behaviour. 


\section{Conclusions}

This paper examines key factors that might affect Australian banks' mortgage pricing behaviour for the period from 1994 to 2003. Firstly, it is the first time in kind to use a simple model to explain and investigate the impacts of both securitisation and resulted market structural change on banks' pricing settings. Lender yield spreads between banks and mortgage corporations, proxing for pricing behaviour, are modelled to be more relevant to the market structural factors (concentration and competition) and securitisation.

Secondly, regression results suggest that lender spreads (four major banks) are positively and significantly related to the two market concentration indexes, and bank market share (proxing for competition), but negatively to securitisation. The findings support what we predict in the simple model and are consistent with securitisation literature (e.g., Gorton and Haubrich, 1995; Kolari et al, 1998) and price-concentration studies (e.g., Berger and Hannan, 1989). Thirdly, Granger Causality findings further indicate the increased competition and declined concentration in the mortgage market led to narrowed lender spreads in terms of adjusting prices by banks to the changing market condition. Improved overall mortgage marketability and liquidity may also have an impact on changes of lender yield spreads. This is also consistent with securitisation-related literature (e.g., Black et al, 1981; Kolari et al, 1998; Narano and Toevs, 2002; Ambrose et al, 2004).

In summary, securitisation has affected lender spreads through changing the mortgage market structure and improving mortgage marketability and liquidity. The findings suggest that securitisation is a key driver to narrowed lender spreads for the period from 1994 to 2003. This is an important finding because previous literature has not directly tested securitisation's exogeneity to lender spreads in terms of bank pricing behaviour. Therefore, these findings provide new evidence on the effects of securitisation.

Australian borrowers are more sensitive to any reductions of interest rates (or costs) because majority of home loans are originated with adjustable rates. The findings provide a very important economic and policy implication for banking regulators and policymakers with respect to improving competition for mortgage lending and mortgage market liquidity. The above results suggest that the heightened competition and declined concentration, and improved mortgage liquidity bring great benefits to 
borrowers in terms of cost savings so banking regulators and policymakers should continue their efforts to further improve them. However, one may argue that the increased competition may also drive lenders to relax their credit standards, such as low documentation loans in Australia and sub-prime mortgages in USA. Therefore banking regulators need to closely regulate and monitor lending practices at the same time as these three aspects should be treated to be equally important to a healthy and sustainable banking system. Further research on this topic may also examine lender credit practices and regulations.

\section{Acknowledgement:}

We would like to thank Professor Chew Ng, Professor Tom Nguyen and Associate Professor Eduardo Roca at Griffith University, Professor Claudia Girardone at University of Essex (U.K.) for their supports, and an anonymous referee for the very constructive comments. We are also indebted to Kathlene Jones of Research and Client Solutions, CANNEX Australia and Australian Prudential Regulation Authority (APRA) for providing data, and various staff of Department of Accounting, Finance and Economics of Griffith University for their assistance. Particular thanks go to Griffith Business School for providing a small research grant that allows completion of the new version of this paper. 


\section{References}

Ambrose, B.W., LaCour-Little, M. and Sanders, A.B. (2004) 'The effects of conforming loan status on mortgage yield spreads: a loan level analysis', Real Estate Economic, Vol. 32, No.4, No. pp.541-569.

Benjamin. J.D., Heuson, A.J., and Sirmans, C.F. (1994) 'The effect of origination strategies on the pricing of fixed-rate mortgage loans', Journal of Housing Research, Vol. 6, No. 1, pp.137-147.

Berger, A. and Hannan, T. (1989) 'The price-concentration relationship in banking', Review of Economics and Statistics, Vol. 7, No. 2, pp.291-299.

Berger, A.N. and Udell, G.F. (1993) 'Securitisation, risk and the liquidity problem in banking', in M. Klausner and L. White (Eds). Structural Changes in Banking, Irwin, Homewood, pp.227-291.

Black, D.G., Garbade, K.D. and Silber, W.L. (1981) 'The impact of the GNMA passthrough program on FHA mortgage costs', Journal of Finance, Vol. 36, No. 2, pp.457-469.

Cetorelli, N. and Strahan, P.E. (2006) 'Finance as a barrier to enter: bank competition and industry structure in local U.S. markets', Journal of Finance, Vol. 61, No, 1, pp.437-461.

Corvoisier, S. and Gropp, R. (2002) 'Bank concentration and retail interest rates', Journal of Banking and Finance, Vol. 26, No.1, pp.2155-2189.

Cumming, C. (1987) 'The economics of securitisation', FRBNY Quarterly Review (Autumn), pp.11-24.

DeMarzo, P.M. (2005) 'The pooling and tranching of securities: a mode of informed intermediation', Review of Financial Studies, Vol. 18, No.1 pp.1-35.

Gilbert, R.A. (1984) 'Bank market structure and competition: a survey', Journal of Money, Credit and Banking, Vol. 16, No.4, pp.617-645.

Gorton, G.B. and Pennacchi, G.G. (1995) 'Banks loan sales: marketing nonmarketable assets', Journal of Monetary Economics, Vol. 35, No.3, pp.389-411.

Gorton, G.B. and Souleles, N.S. (2005) 'Special purpose vehicle and securitisation', Working Paper No.05-21. Wharton School, University of Pennsylvania and NBER.

Greenbaum, S.I. and Thakor, A.V. (1987) 'Banking funding modes: securitisation versus deposits', Journal of Banking and Finance, Vol. 11, No.3, pp.379-402. 
Gujarati, D.N. (2003) Basic Econometrics, 4th edition, Boston: McGraw Hill.

Hess, A., and Smith, Jr, C. (1988), 'Elements of mortgage securitisation', Journal of Real Estate Finance and Economics, Vol. 1, No.4, pp.331-346.

Hendershott, P.H. and Shilling, J.D. (1989) 'The impact of the agencies on conventional fixed-rate mortgage yields', Journal of Real Estate Finance and Economics, Vol. 2, No.2, pp.101-115.

Hill, C.A. (1997) 'Securitisation: a low-cost sweetener for lemons', Journal of Applied Corporate Finance, Vol. 10, No.1, pp.64-71.

Iacobucci, E.M. and Winter, R.A. (2005) 'Asset securitisation and asymmetric information', Journal of Legal Studies, Vol. 34, No.1, pp.161-206.

Kolari, J.W., Fraser, D.R. and Anari, A. (1998) 'The effects of securitisation on mortgage market yields: a cointegration analysis', Real Estate Economics, Vol. 26, No.4, pp.667-677.

Kothari, V. (2006) Securitisation: The financial instruments of the future, Singapore: John Willey \& Sons (Asia) Pte Ltd.

Kumar, J. and Ralston, D. (1999) 'The growth of mortgage managers and their impact on the Australian home loan market', Accounting Research Journal, Vol. 12, No.1, pp.45-53.

Liu, B. and Skully, M. (2005) 'The determinants of mortgage yield spread differentials: securitisation', Journal of Multinational Financial Management, Vol. 15, No.4-5, pp.314-333.

Naranjo, A. and Toevs, A. (2002) 'The effects of purchases and securitisation by government sponsored enterprises on mortgage yield spreads and volatility', Journal of Real Estate and Economics, Vol. 25, No.2-3, pp.173-195.

O'Connell, B. (1997) 'The impact of mortgage originations on the Australian banking markets - driving competition on the banks', The Australian Bankers, Vol. 111, No.3, pp.7-8.

Rousseas, S. (1985) 'A markup theory of bank loan rates', Journal of Post Keynesian Economics, Vol. 8, No.1, pp.135-144.

SA-AADU, J.D. Shilling, J.D. and Wang, G.H.K. (2000) 'A Test of Integration and Cointegration of commercial mortgage rates', Journal of Financial Services Research, Vol .18, No. 1, pp.45-61. 
Schwarcz, S.L. (1994) 'The alchemy of asset securitisation', Stanford Journal of Law Business and Finance, Vol. 1, No.1, pp.133-154.

Thomas, H., and Wang, Z. (2003) 'Why bank securitise assets', Conference paper of the $16^{\text {th }}$ Australasian Banking and Finance Conference, 15-17 December, Sydney, Australia.

Wolfe, S. (2000), 'Structural effects of assets-backed securitisation', The European Journal of Finance, Vol 6, No.4, 353-369. 
Table 1 Variables and their definitions

\begin{tabular}{|c|c|c|}
\hline Short Form & Variables & Definitions \\
\hline LSP & Lender yield spreads & $\begin{array}{l}\text { Standard adjustable interest rates differences between } \\
\text { banks and mortgage corporations }\end{array}$ \\
\hline BMS & $\begin{array}{l}\text { Bank market share, proxy for } \\
\text { Competition (expected positive to } \\
\text { the spread, }+ \text { ) }\end{array}$ & $\begin{array}{l}\text { The four major bank market share in overall owner- } \\
\text { occupied mortgage outstanding }\end{array}$ \\
\hline BIMSa & $\begin{array}{l}\text { Bank industry market share } \\
\text { proxy for competition } \\
\text { (expected positive to the spread, }+ \text { ) }\end{array}$ & $\begin{array}{l}\text { Bank industry market share of the residential mortgage } \\
\text { market }\end{array}$ \\
\hline $\mathrm{BIMSb}$ & $\begin{array}{l}\text { Bank industry new loan market } \\
\text { share proxy for competition } \\
\text { (expected positive to the spread, }+ \text { ) }\end{array}$ & $\begin{array}{l}\text { Bank industry newly originated market share of } \\
\text { residential loans }\end{array}$ \\
\hline HHIa & $\begin{array}{l}\text { Market concentration index-a } \\
\text { Herfindahl-Hirschman Index } \\
\text { (expected positive to the spread, }+ \text { ) }\end{array}$ & $\begin{array}{l}\text { Sum of squared outstanding market share of bank, } \\
\text { building society, credit union and mortgage corporation } \\
\text { groups }\end{array}$ \\
\hline HHIb & $\begin{array}{l}\text { Market concentration index-b } \\
\text { Herfindahl-Hirschman Index } \\
\text { (expected positive to the spread, }+ \text { ) }\end{array}$ & $\begin{array}{l}\text { Sum of squared new loan market share of bank, } \\
\text { building society, credit union and mortgage corporation } \\
\text { groups }\end{array}$ \\
\hline SECTZ & $\begin{array}{l}\text { Marketability and liquidity change } \\
\text { (expected negative to the spread, -) }\end{array}$ & Annual growth rate of overall mortgage securitisation \\
\hline Yr94-03 & Year dummy (trends) & From 1994 to 2003 \\
\hline
\end{tabular}


Table 2 Regression analysis results in Models 1, 2 and 3

\begin{tabular}{llll} 
Panel A: Model 1 & & & \\
Variables & Coefficient & Std. Error & $t$-Statistic \\
INTERCEPT & 0.722 & 0.091 & $7.914^{\mathrm{a}}$ \\
BMS & 1.716 & 0.609 & $2.817^{\mathrm{a}}$ \\
SECTZ & $(0.833)$ & 0.088 & $(9.466)^{\mathrm{a}}$ \\
$R^{2}$ & 0.205 & $F$-Statistic & 49.743 \\
Adj. $R^{2}$ & 0.201 & $p$-value & 0.000 \\
\hline Panel B: Model 2 & & & \\
\hline Variables & Coefficient & Std. Error & $t$-Statistic \\
INTERCEPT & $(5.461)$ & 0.321 & $(16.991)^{\mathrm{a}}$ \\
HHIa & 8.721 & 0.435 & $20.033^{\mathrm{a}}$ \\
SECTZ & $(0.661)$ & 0.063 & $(10.523)^{\mathrm{a}}$ \\
$R^{2}$ & 0.603 & $F$-Statistic & 292.276 \\
Adj. $R^{2}$ & 0.601 & $p$-value & 0.000 \\
\hline Panel C: Model 3 & & & \\
\hline Variables & Coefficient & Std. Error & $t$-Statistic \\
INTERCEPT & $(2.440)$ & 0.351 & $(6.946)^{\mathrm{a}}$ \\
HHIb & 4.444 & 0.457 & $9.713^{\mathrm{a}}$ \\
SECTZ & $(0.239)$ & 0.101 & $(2.364)^{\mathrm{b}}$ \\
$R^{2}$ & 0.349 & $F$-Statistic & 103.020 \\
Adj. $R^{2}$ & 0.345 & $p$-value & 0.000 \\
\hline & & & \\
\hline
\end{tabular}

Note: $\mathrm{a}, \mathrm{b}$ and $\mathrm{c}$ denotes the 1,5 and 10 percent levels of significance respectively.

$L S P=\beta_{0}+\beta_{1}[B M S ; H H I a ; H H I b]_{i}+\beta_{2} S E C T Z_{i}+\varepsilon_{i}$

Where LSP is the spreads of four major banks over mortgage corporations for the period from January 1994 to December 2002; SECTZ; BMS, monthly market share of each of four major bank; SECTZ, marketability and liquidity change via annual growth rate of overall mortgage securitisation; HHIa for the Herfindahl-Hirschman Index of residential loan outstanding as a measure of concentration; HHIb for the Herfindahl-Hirschman Index of the newly originated residential loan as a another measure of concentration. 
Table 3 Regression analysis results in Model 4

\begin{tabular}{llll} 
Panel D: Model 4 & & & \\
Variables & Coefficient & Std. Error & $t$-Statistic \\
INTERCEPT & $(1.689)$ & 1.014 & $(1.666)^{\mathrm{a}}$ \\
HHIA & 3.669 & 1.323 & $2.788^{\mathrm{b}}$ \\
SECTZ & $(0.662)$ & 0.115 & $(5.735)^{\mathrm{a}}$ \\
Yr1995 & 0.224 & 0.049 & $4.610^{\mathrm{a}}$ \\
Yr1996 & 0.405 & 0.085 & $4.795^{\mathrm{a}}$ \\
Yr1997 & $(0.274)$ & 0.089 & $(3.079)^{\mathrm{a}}$ \\
Yr1998 & $(0.326)$ & 0.080 & $(4.049)^{\mathrm{a}}$ \\
Yr1999 & $(0.377)$ & 0.094 & $(4.032)^{\mathrm{a}}$ \\
Yr2000 & $(0.264)$ & 0.120 & $(2.201)^{\mathrm{b}}$ \\
Yr2001 & $(0.161)$ & 0.101 & $(1.588)$ \\
Yr2002 & $(0.273)$ & 0.118 & $(2.326)^{\mathrm{b}}$ \\
\hline$R^{2}$ & 0.823 & $F$-Statistic & 175.598 \\
$A d j . R^{2}$ & 0.819 & $p$-value & 0.000 \\
\hline
\end{tabular}

Note: $\mathrm{a}, \mathrm{b}$ and $\mathrm{c}$ denotes the 1,5 and 10 percent levels of significance respectively.

$L S P=\beta_{0}+\beta_{1} \mathrm{HHIA}_{i}+\beta_{2} \mathrm{SECTZ}_{i}+\Sigma \beta_{k}$ Year $_{k}+\varepsilon_{i}$

Where LSP is the spreads of four major banks over mortgage corporations for the period from January 1994 to December 2002; SECTZ, marketability and liquidity change via annual growth rate of overall mortgage securitisation; HHIa for the Herfindahl-Hirschman Index of residential loan outstanding as a measure of concentration; Year, from 1994 to 2002, taking 1994 as the reference. 
Table $4 \quad F$-Statistics of the Granger Causality test for lender yield spreads

\begin{tabular}{|c|c|c|c|c|c|c|c|c|}
\hline \multirow[t]{2}{*}{ lag } & & & 1 & 2 & 3 & 4 & 5 & 6 \\
\hline & & \multicolumn{7}{|c|}{$F$-statistics } \\
\hline \multicolumn{9}{|l|}{ Panel A } \\
\hline$\triangle B I M S a$ & $\rightarrow$ & $\triangle L S P$ & $5.5379^{\mathrm{b}}$ & $3.2336^{\mathrm{b}}$ & 0.9538 & 0.7984 & 0.5272 & 0.5340 \\
\hline$\triangle B I M S b$ & $\rightarrow$ & $\triangle L S P$ & $15.5141^{\mathrm{a}}$ & $9.3357^{\mathrm{a}}$ & $3.0417^{\mathrm{b}}$ & 1.8498 & 1.8799 & 1.8360 \\
\hline$\Delta H H I a$ & $\rightarrow$ & $\Delta L S P$ & $5.9444^{\mathrm{b}}$ & $3.5339^{\mathrm{b}}$ & 1.1133 & 0.9240 & 0.6199 & 0.6241 \\
\hline$\Delta H H I b$ & $\rightarrow$ & $\triangle L S P$ & $18.3132^{\mathrm{a}}$ & $11.5079^{\mathrm{a}}$ & $3.9820^{\mathrm{b}}$ & $2.5574^{\mathrm{b}}$ & $2.5204^{\mathrm{b}}$ & $2.4936^{\mathrm{b}}$ \\
\hline$\triangle \mathrm{SECTZ}$ & $\rightarrow$ & $\triangle L S P$ & $5.6612^{\mathrm{b}}$ & $4.1172^{\mathrm{b}}$ & 0.8031 & 0.6469 & 0.4051 & 0.8554 \\
\hline \multicolumn{9}{|l|}{ Panel B } \\
\hline$\triangle L S P$ & $\rightarrow$ & $\triangle B I M S a$ & 0.4909 & 0.3881 & 0.3375 & 0.2303 & 0.1578 & 0.3257 \\
\hline$\triangle L S P$ & $\rightarrow$ & $\triangle B I M S b$ & $3.3515^{\mathrm{c}}$ & 0.0118 & 0.18237 & 0.38553 & 0.31799 & 0.42488 \\
\hline$\triangle L S P$ & $\rightarrow$ & $\Delta H H I a$ & 0.4374 & 0.3713 & 0.3347 & 0.2277 & 0.1530 & 0.3470 \\
\hline$\triangle L S P$ & $\rightarrow$ & $\Delta H H I b$ & $4.8003^{\mathrm{b}}$ & 0.06433 & 0.22704 & 0.54153 & 0.42346 & 0.55789 \\
\hline$\triangle L S P$ & $\rightarrow$ & $\triangle \mathrm{SECTZ}$ & $4.0328^{\mathrm{b}}$ & 2.1400 & 2.1651 & 1.7205 & 1.9323 & 1.0242 \\
\hline Obs. & & & 119 & 118 & 117 & 116 & 115 & 114 \\
\hline
\end{tabular}

Note: $\rightarrow$ denotes the direction of Granger Causality. The following regressions are used as:

$$
\begin{aligned}
& \Delta \mathrm{Y}_{t}=\alpha_{y}+\sum_{i=1}^{k} \beta y, i \Delta \mathrm{Y}_{t-i}+\sum_{i=1}^{k} \lambda \mathrm{y}, i \Delta \mathrm{X}_{t-i}+\varepsilon_{y, t} \\
& \Delta \mathrm{X}_{t}=\alpha_{x}+\sum_{i=1}^{k} \beta x, i \Delta \mathrm{X}_{t-i}+\sum_{i=1}^{k} \lambda \mathrm{x}, i \Delta \mathrm{Y}_{t-i}+\varepsilon_{x, t}
\end{aligned}
$$

$\Delta \mathrm{Y}$ is the first difference of the spreads of banks over mortgage corporations at time; $\Delta \mathrm{X}$ is the first difference of market share, concentration index and marketability respectively. Where, $\Delta$ denotes first difference; LSP stands for spreads of banks over mortgage corporations from January 1994 to December 2003; BIMSa for banks' market share of the residential mortgage market; BIMSb for banks' newly originated market share of residential loans; HHIa for the Herfindahl-Hirschman Index of residential loan outstanding as a measure of concentration; HHIb for the Herfindahl-Hirschman Index of the newly originated residential loan as a another measure of concentration; and, SECTZ, the growth of securitisation, proxying for overall mortgage market marketability and liquidity.

$\mathrm{a}, \mathrm{b}$ and $\mathrm{c}$ denotes the 1,5 and 10 percent levels of significance respectively. 
Notes:

${ }^{1}$ B19 securitisation vehicles, Reserve Bank of Australia (2004) is at www.rba.gov.au.

${ }^{2}$ They are also known as mortgage mangers or wholesale lenders in Australia, e.g., Aussie Home Loan, which focus their business on mortgage originations, servicing, etc, Their funding is virtually raised from the capital markets by issuing mortgage-backed securities (MBS). Unlike commercial banks, they do not raise funds from deposits taking. Instead they originate mortgages and sell them to other securitisers or securitize their assets through their own programs in the capital market.

${ }^{3}$ The four major banks are National Australia Bank (NAB), Commonwealth Bank of Australia (CBA), Australia and New Zealand Banking Corporation (ANZ), and Westpac Banking Corporation (Westpac). They are also known as "four pillar" banks.

${ }^{4}$ Sometimes it is also known as structure-conduct-performance hypothesis in literature.

${ }^{5}$ Berger and Udell (1993) extensively discuss early securitisation literature. They summarise seven hypotheses in literature of the competing hypotheses before 1992 in relation to securitisation, loan sales and bank behaviour. More details on each one can be found in their study. After 1992 other authors offer more hypotheses, e.g. cost of funding, diversification of funding, disintermediation, etc.

${ }^{6}$ There are no reserve and deposit insurance requirements in Australia.

${ }^{7}$ As the author states that the non-financial sector of production, markup theory assumes an economy with a large concentration of market power. Oligopolistic firms operate at a planned level of excess capacity and the degree of monopoly in each industry permits a markup over unit prime costs (Kalecki, 1971, cited in Rousseas, 1985). Rousseas further compares cost composition for banks and non-bank firms. Total costs comprise of fixed costs and variable costs. Fixed costs for a non-bank firm consist of certain fixed or overhead costs and prime costs (variable costs) include labours, raw materials, etc. The degree of monopoly, or gross profit margin, which has been relatively stable over the long term, represents the markup over prime costs that determine the price of goods consistent with its profit goals. For a bank, besides the overhead, fixed costs include labour costs, which are also known as operating costs. 'Raw materials' of a bank are deposit and borrowed funds. Prime costs are the interest paid on deposits and on the borrowed funds. Market structure is ignored.

${ }^{8}$ Gilbert (1984) extensively reviews early research on the relation between bank product pricing and market concentration for the period from 1955 to 1981. Almost all suggest that an increase of market concentration has a rise in rates to loans and a drop to deposits.

${ }^{9}$ Liu and Skully (2005) summarise their respective cost and other characteristics.

${ }^{10} R$ stands for return, ${ }^{n}$ for normal and ${ }^{e x}$ for excess.

${ }^{11}$ In addition to funding cost, $\mathrm{C}$ includes a range costs due to risks, such as default risk, prepayment risk, liquidity risk, etc.

${ }^{12}$ The major banks often have a greater capacity to extract higher fees and margins from their customer base than newer competitors. This is because the major banks are likely to possess a higher proportion of customers who are less likely to "shop around" for a better overall deal on their mortgage than other market participations.

${ }^{13}$ Empirical work on the integration of these two markets can be found in Kumar and Ralston (1999) and Sa-Aadu, Shilling and Wang, (2000).

${ }_{15}^{14}$ Herfindahl-Hirschman Index (see Table 1)

${ }^{15}$ Based on the RBA the bank rate is the average figure of four major banks, including National Australia Bank (NAB), Commonwealth Bank of Australia (CBA), Australia and New Zealand Banking Corporation (ANZ), and Westpac Banking Corporation (Westpac). Similarly, the rate for mortgage corporations accounts for major mortgage corporations. More details on these can be found at www.rba.org.au.

${ }^{16}$ Gujarati (2003) provides details on popularity of using this test since1970s. Before conducting this analysis, series variables are determined whether they are stationary, $\mathrm{I}(0)$ or non stationary, $\mathrm{I}(1)$. The determination of a series, I(1) depends on whether it contains a unit root. We employ two tests to detect the existence of a unit root: Dickey-Fuller test (ADF) and Phillips and Perron (PP). Due to the paper length, details on these two statistics are excluded here.

${ }^{17}$ Before using the first difference, series variables are determined whether they are stationary, $I(0)$ or non stationary, $I(1)$. The determination of a series, $I(1)$ depends on whether it contains a unit root. We employ two tests to detect the existence of a unit root: Dickey-Fuller test (ADF) and Phillips and Perron (PP). Both test results can not reject the null hypothesis so we use the first differences. Due to the paper length, details on these two statistics are excluded here. Results of ADF and PP tests for all the series from 1 to 6 lags suggest that their first difference rejects the null hypothesis that there is a unit root at the 0.01 level. 